\title{
In-vitro prostanoid production by the rat vas deferens
}

\author{
K. Gerozissis and F. Dray \\ INSERM U.207-Institut Pasteur, U.R.I.A., 28 Rue du Dr. Roux, 75724 Paris Cedex 15, France
}

\begin{abstract}
Summary. Prostaglandins (PGs), E-2, F-2 $\alpha, 6$-keto-F-1 $\alpha$ and thromboxane B-2 (TXB2 ), produced in vitro by the vas deferens of rats at different stages of sexual maturation (10,35 and 100 days of age), were estimated by radioimmunoassay. Reversed-phase high-performance liquid chromatography was used to evaluate the RIA and to give a more complete profile, after incubation of the vas deferens with $\left[{ }^{14} \mathrm{C}\right]$ arachidonic acid. The amount of PGE- 2 released into the medium after incubation at $37^{\circ} \mathrm{C}$ for $5 \mathrm{~min}$ increased with age, and was the predominant prostanoid in the adult vas deferens. In prepubertal organs, 6-keto-PGF-1 $\alpha$ predominated. TXB- 2 was always a minor product. The addition of exogenous arachidonic acid $(10 \mu \mathrm{g} / \mathrm{ml} / 20 \mathrm{mg}$ tissue $)$, provoked a higher production of the four compounds. PGE-2 and PGF- $2 \alpha$ levels were reduced after castration or hypophysectomy and were re-instated after treatment with testosterone propionate. PGE-2 was much more sensitive to hormonal deprivation than PGF-2 $\alpha$. The production of 6-keto-PGF-l $\alpha$ was not significantly affected by the above treatments.
\end{abstract}

\section{Introduction}

Prostaglandins (PG) E-2 and F-2 $\alpha$ have been found in the testis, epididymis and vas deferens of prepubertal and adult rats. The respective amounts change differently in each tissue during sexual maturation: basal levels are similar and without significant modifications of their ratio in the testis whilst an isolated and dramatic increase of PGE-2 occurs in the cauda epididymidis at 35 days of age. In the vas deferens, which contains the highest amounts of PGE- 2 and PGF- $2 \alpha$, a progressive increase of PGE-2 is observed with age (Carpenter, 1974; Gerozissis \& Dray, 1977a, b; Johnson \& Ellis, 1977). The basal level of these two prostanoids in the vas deferens of prepubertal rats was found to be affected by androgens: a marked decrease occurred after castration or hypophysectomy and a dose-dependent increase after testosterone administration (Dray \& Gerozissis, 1979).

In this study, we have evaluated the amounts of several prostanoids produced in vitro by the vas deferens and investigated further the prostanoid-androgen relationships.

\section{Materials and Methods}

All unlabelled PGs were a gift from the Upjohn Company (Kalamazoo, Michigan, U.S.A.). Arachidonic acid and testosterone propionate were provided by Sigma, $5 \alpha$-dihydrotestosterone propionate by Steraloids; tritium-labelled PGE-2 and PGF- $2 \alpha$ (sp. act. $160 \mathrm{Ci} / \mathrm{mmol}$ ) were from Amersham. Tritium-labelled 6-keto-PGF-1 $\alpha$, thromboxane (TX) B-2 and ${ }^{14} \mathrm{C}-$ labelled arachidonic acid were obtained from New England Nuclear (sp. act. 120, 100 and $250 \mathrm{Ci} / \mathrm{mmol}$, respectively). 
${ }^{125} \mathrm{I}$-labelled histamine, 6-keto-PGF-1 $\alpha$, TXB-2 and PG antisera were prepared in our laboratory as previously described (Sors et al., 1978; Dray et al., 1980). The binding characteristics of the selected antisera for this study are given in Table 1.

Table 1. Binding characteristics of the prostanoid antisera

\begin{tabular}{|c|c|c|c|c|c|c|c|c|c|c|c|}
\hline \multirow[b]{2}{*}{ Antiserum } & \multirow[b]{2}{*}{$\begin{array}{c}\text { Final } \\
\text { dilution }\end{array}$} & \multirow[b]{2}{*}{ Tracer } & \multirow[b]{2}{*}{$\begin{array}{l}\text { Sensitivity* } \\
\text { (pg/tube) }\end{array}$} & \multicolumn{8}{|c|}{ Specificity against various prostanoids $\dagger$} \\
\hline & & & & $\mathrm{E}-2$ & $F-2 \alpha$ & D-2 & 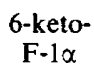 & TXB-2 & E-1 & $F-1 \alpha$ & D-1 \\
\hline $\begin{array}{c}\text { Anti-PGE-2 } \\
(79585)\end{array}$ & $8 \times 10^{-5}$ & {$\left[{ }^{3} \mathrm{H}\right] \mathrm{PGE}-2$} & 4 & 100 & $0-06$ & $<0.01$ & $<0.01$ & $<0.01$ & $3 \cdot 2$ & $<0.01$ & 一 \\
\hline $\begin{array}{l}\text { Anti-PGF-2 } \alpha \\
(5 G)\end{array}$ & $1.1 \times 10^{-5}$ & {$\left[{ }^{3} \mathrm{H}\right] \mathrm{PGF}-2 \alpha$} & 11 & $<0.15$ & 100 & 22 & $1 \cdot 8$ & - & 0.25 & 29 & 5 \\
\hline $\begin{array}{l}\text { Anti-6-keto- } \\
\quad F-1 \alpha(2673)\end{array}$ & $1.2 \times 10^{-5}$ & $\begin{array}{c}{[125 I] \text { histamine }-} \\
6-\text { keto-F-1 } \alpha\end{array}$ & 16 & $2 \cdot 20$ & $10 \cdot 9$ & 0.5 & 100 & $<0 \cdot 10$ & $5 \cdot 60$ & $18 \cdot 2$ & $1 \cdot 5$ \\
\hline $\begin{array}{c}\text { Anti-TXB-2 } \\
(79587)\end{array}$ & $1.5 \times 10^{-4}$ & $\begin{array}{l}\text { ['25I]histamine- } \\
\text { TXB-2 }\end{array}$ & $10 !$ & $<0 \cdot 10$ & $<0 \cdot 1$ & $<0.5$ & $<0.01$ & 100 & - & - & - \\
\hline
\end{tabular}

* Expressed as the quantity (pg) necessary for $50 \%$ tracer displacement with the corresponding PG.

† Calculated on the basis of the quantity (pg) of a given inhibitor necessary for $50 \%$ tracer displacement. The other prostanoids tested (A-2, B-2, DHKE-2, DHKF- $2 \alpha, \mathrm{A}, \mathrm{B}$ ) cross-reacted $<0 \cdot 2 \%$.

Instruments and columns for reversed-phase high-performance liquid chromatography (rpHPLC) were from Waters Associates. Male Wistar rats (Albinos-Institut, Philadelphia, U.S.A.) were provided by Cesal and Iffa Credo, France.

The rats were killed by prolonged chloroform anaesthesia at appropriate ages. Bilateral castration was performed under ether anaesthesia; the epididymides were not removed. Castration and hypophysectomy were performed at 21 days of age. Androgens diluted in sesame oil, were administered s.c. $(250 \mu \mathrm{g} / 0 \cdot 2 \mathrm{ml})$ daily beginning on the day of operation, until Day 34 of age.

Each organ was removed, weighed and plunged into ice-cold $0.1 \mathrm{M}$-phosphate buffer, $\mathrm{pH} 7 \cdot 4$ for about $20 \mathrm{~min}$, until incubated. The buffer was discarded and the incubation performed at $37^{\circ} \mathrm{C}$ for 5 $\mathrm{min}$ in freshly added buffer. The tissue $(20 \mathrm{mg} / \mathrm{ml}$ of buffer) was incubated in the presence or absence of exogenous arachidonic acid $(10 \mu \mathrm{g} / \mathrm{ml})$, in a shaking bath. The incubation medium after removal of the tissues was frozen and stored in liquid nitrogen until assayed for prostanoids. The metabolites were extracted from the medium with ethyl acetate after acidification at $\mathrm{pH} 4$. The RIA was performed as previously described (Dray, Charbonnel \& Maclouf, 1975; Dray et al., 1980). The non-specific binding (incubation buffer, extracted and analysed as above) was $90 \pm$ $10 \%$. The recovery of tritiated prostanoids $(\simeq 1500$ d.p.m., added before acidification) was $>80 \%$. These two parameters were checked in all assays.

The rp-HPLC performed after extraction and purification on silicic acid columns was introduced to check the specificity of each RIA or to establish the profile of radioactive metabolites synthesized from $\left[{ }^{14} \mathrm{C}\right]$ arachidonic acid. The eluate containing prostanoids was evaporated at $37^{\circ} \mathrm{C}$ under a stream of nitrogen. Ethyl acetate $(1 \mathrm{ml})$ was added and stored at $-20^{\circ} \mathrm{C}$. The samples were evaporated to dryness, dissolved in $200 \mu \mathrm{l}$ of the elution solvent and, after centrifugation ( $15 \mathrm{~min}$, $4000 \mathrm{~g}, 4^{\circ} \mathrm{C}$ ), were applied to the column. The conditions of rp-HPLC were as follows: reversedphase column, $\mu$ Bondapack $\mathrm{C}_{18}, 3.9 \mathrm{~mm} \times 30 \mathrm{~cm}$; mobile phase, water/acetonitrile/acetic acid/benzene $(76 \cdot 7: 23: 0 \cdot 2: 0 \cdot 1$ by vol.), flow rate, $2 \mathrm{ml} / \mathrm{min}$, isocratic elution. The column pressure was continuously recorded. Fractions were collected every minute in plastic microtubes, frozen at $-80^{\circ} \mathrm{C}$ and freeze dried. The freeze dried material was resuspended into an appropriate volume of RIA buffer and an aliquant was taken to determine the recovery of radioactivity $(>70 \%)$. The immunoreactive value obtained after rp-HPLC for each prostanoid was very similar to that 
obtained after extraction and justified simplifying the procedure, as shown in the following pilot experiment.

$\begin{array}{lccc} & \text { PGE-2 } & \text { PGF-2 } \alpha & \text { 6-keto-PGF-1 } \alpha \\ \text { Before rp-HPLC } & 1420 & 378 & 820 \\ \text { After rp-HPLC } & 1275 & 333 & 726\end{array}$

Student's $t$ test was used for statistical analysis.

\section{Results}

\section{Basal production of prostanoids in vitro in different stages of sexual maturation}

PGE-2 and PGF-2 $\alpha$ were the dominant prostanoids in prepubertal and adult rats (Table 2). The stable derivative of PGI-2, 6-keto-PGF-1 $\alpha$ was the predominant prostanoid in 10-day-old rats, but was significantly reduced at 35 days of age. TXB-2, the stable metabolite of TXA-2, was always very low and without significant modifications with age.

Table 2. Concentration (ng/g tissue) of prostanoids in the incubation medium after incubation $(5 \mathrm{~min}$ ) of the vas deferens tissue of rats at different stages of sexual development

\begin{tabular}{|c|c|c|c|c|c|}
\hline $\begin{array}{c}\text { Age } \\
\text { (days) }\end{array}$ & $\begin{array}{c}\text { No. of } \\
\text { exps }\end{array}$ & PGE-2 & PGF- $2 \alpha$ & 6-keto-PGF-1 $\alpha$ & TXB-2 \\
\hline \multicolumn{6}{|c|}{ In absence of exogenous precursor } \\
\hline 10 & 14 & $20 \pm 6$ & $14 \pm 2$ & $96 \pm 22$ & $8 \pm 1$ \\
\hline 35 & 9 & $* 50 \pm 7$ & $* 43 \pm 15$ & $* 35 \pm 16$ & $6 \pm 2$ \\
\hline 100 & 9 & ${ }^{*} 141 \pm 39$ & $* 106 \pm 13$ & $* 67 \pm 17$ & $10 \pm 3$ \\
\hline \multicolumn{6}{|c|}{ In presence of exogenous arachidonic acid $\dagger$} \\
\hline 10 & 9 & $115 \pm 37$ & $75 \pm 6$ & $495 \pm 95$ & $15 \pm 5$ \\
\hline 35 & 6 & $* 293 \pm 33$ & $* 175 \pm 15$ & $574 \pm 250$ & $* 27 \pm 3$ \\
\hline 100 & 10 & ${ }^{*} 1512 \pm 880$ & $* 436 \pm 219$ & $617 \pm 348$ & ${ }^{*} 108 \pm 43$ \\
\hline
\end{tabular}

Values are mean \pm s.e.m.

* Significantly different from preceding group $(P<0.01)$.

$\dagger 10 \mu \mathrm{g} / \mathrm{ml}$ per $20 \mathrm{mg}$ tissue.

The addition of exogenous arachidonic acid provoked an increased production of the four compounds with substantial differences (Table 2): 6-keto-PGF-1 $\alpha$ was predominant at 10 and 35 days (much higher than PGE-2 and PGF- $2 \alpha$ values), PGE-2 was predominant in adults (values significantly different) and TXB-2 was present in the lowest concentrations although an increase was observed with age. Application of rp-HPLC to the radioactive prostanoids obtained by incubation of adult rat vas deferens in the presence of $\left[{ }^{14} \mathrm{C}\right]$ arachidonic acid and after extraction and silicic acid chromatography (Text-fig. 1) showed that the most important peaks co-migrated respectively with PGE-2, PGF-2 $\alpha$, 6-keto-PGF-1 $\alpha$ and another metabolite of PGI-2, 6,15-diketoPGF-1 $\alpha$. The peaks corresponding to TXB-2 or PGD-2 were very small.

\section{Effects of various manipulations on prostanoid production}

PGE-2 production was dramatically reduced after hypophysectomy and even more so after castration in immature and adult rats $(P<0.005)$. PGF-2 $\alpha$ production was reduced to a lesser degree; the reduction was statistically significant in adult rats $(P<0.005$; Text-fig. 2$)$, but not in prepubertal animals $(P>0.05)$. 


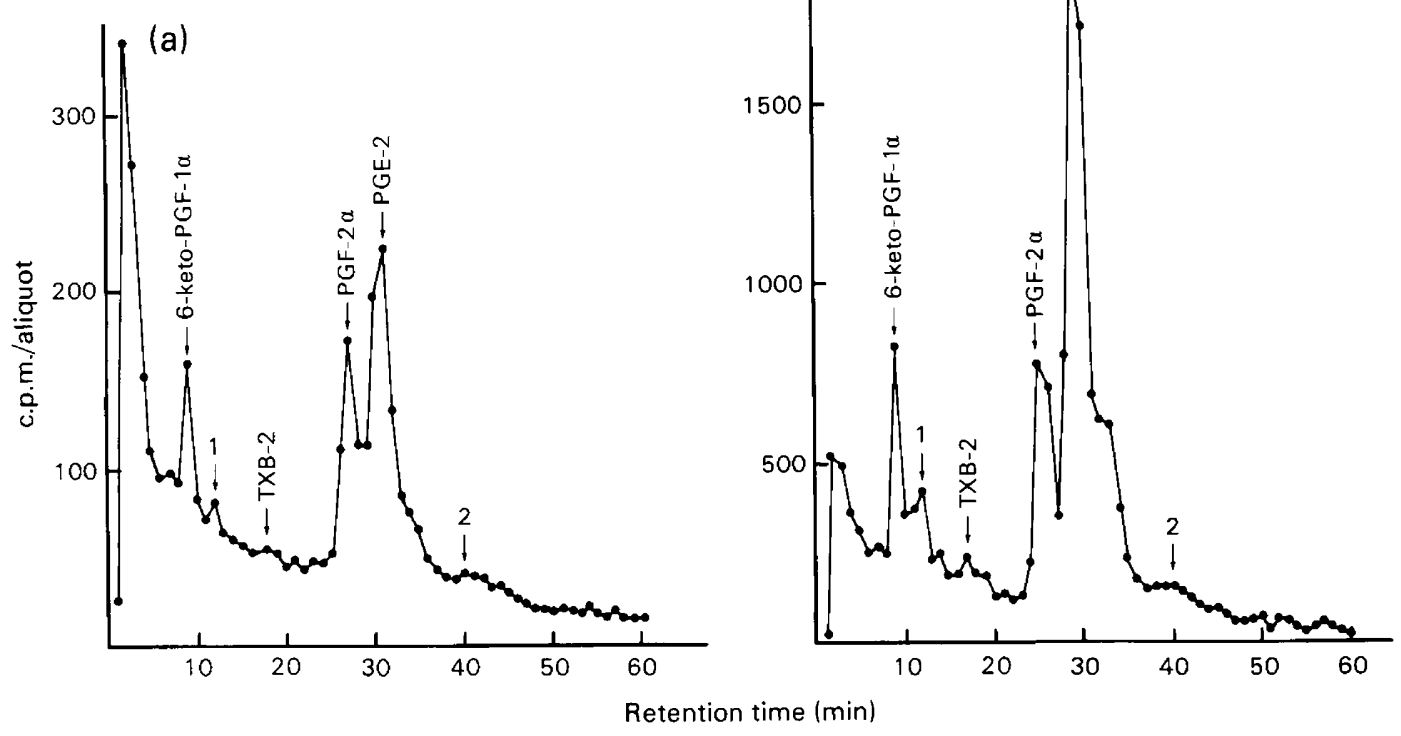

Text-fig. 1. In-vitro metabolism of $\left[{ }^{14} \mathrm{C}\right]$ arachidonic acid by adult rat vas deferens incubated at $37^{\circ} \mathrm{C}$ for (a) $5 \mathrm{~min}$ and (b) $60 \mathrm{~min}$. The prostanoid profile was established after rp-HPLC. Peaks 1 and 2 correspond to standard 6,15-diketo-PGF-1 $\alpha$ and PGD-2 retention times respectively.

Testosterone propionate administration $(250 \mu \mathrm{g} /$ day $)$ to castrated animals, starting on the day of operation and for 14 days thereafter, resulted in a significant increase in PGE-2 and PGF-2 $\alpha$ above the control levels in immature rats but did not reach the control values in adult rats (Text-fig. 2): the same dose had less effect after hypophysectomy. Production of 6-keto-PGF- $1 \alpha$ was not significantly affected after castration, hypophysectomy or castration and testosterone propionate treatment in adult rats $(P>0.05)$. Values of this prostanoid were reduced after castration of 35day-old rats $(P<0.05)$. Hypophysectomy or castration and testosterone propionate treatment did not affect 6-keto-PGF-1 $\alpha$ in prepubertal or adult rats (Text-fig. $2, P>0.05$ ).

The administration of $5 \alpha$-dihydrotestosterone propionate $(250 \mu \mathrm{g} / \mathrm{day})$ after hypophysectomy resulted in effects similar to those found with testosterone propionate (see Text-fig. 3 as an example for PGE-2).

\section{Discussion}

The rat vas deferens in vitro produces and releases into the incubation medium PGE-2, PGF-2 $\alpha$, 6keto-PGF- $1 \alpha$ and TXB- 2 in varying amounts according to the stage of sexual development. PGE-2 is dominant in the tissue of adults in the absence of exogenous substrate and in the presence of unlabelled or $\left[{ }^{14} \mathrm{C}\right]$ arachidonic acid. TXB-2 was always the minor product. It is possible that TXB-2 originates from platelets sequestered in the tissue. The prostacyclin pathway, measured as 6-ketoPGF- $1 \alpha$, predominated in 10-day-old rats. The ratio of 6-keto-PGF-1 $\alpha:$ PGE-2+PGF- $2 \alpha$ decreases with sexual maturation. Similar results are obtained in the immature rat testis and epididymis (unpublished observations), and this may be a general phenomenon in the male rat 


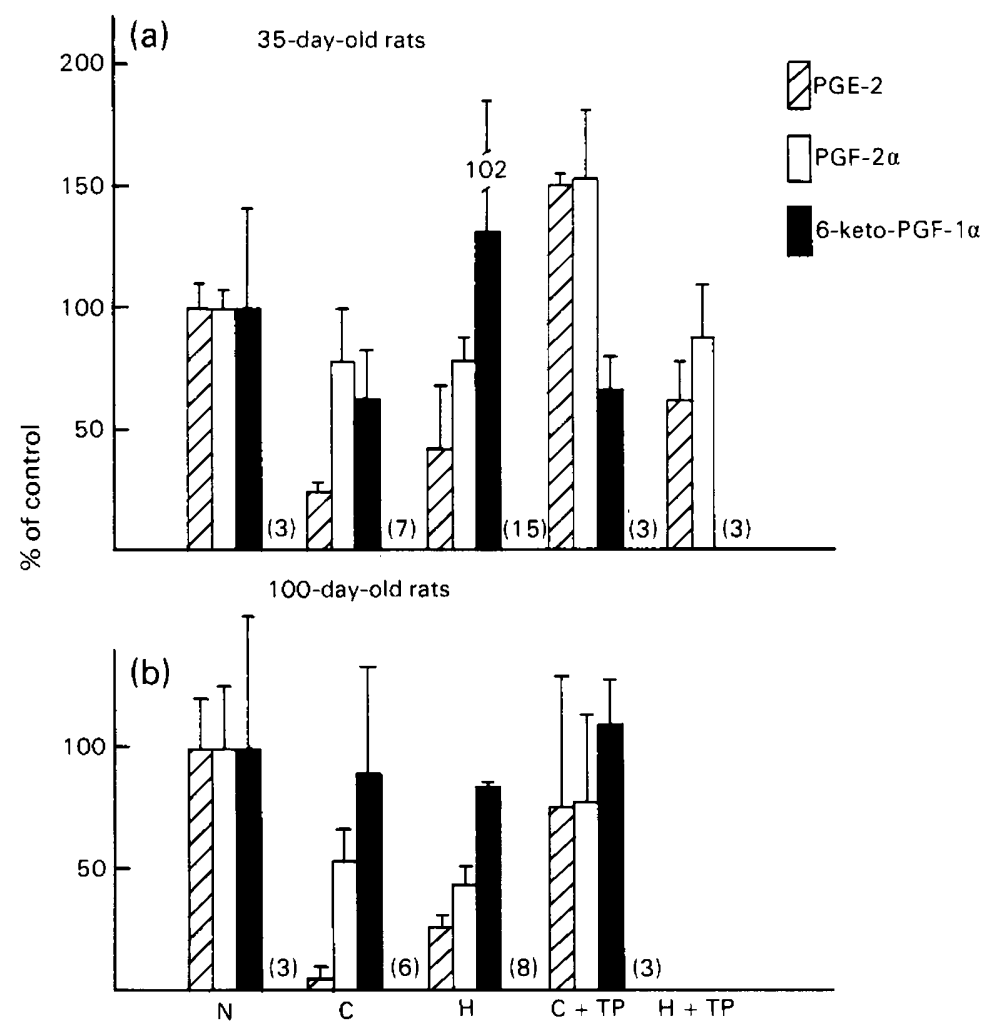

Text-fig. 2. Effect of hypophysectomy (H), castration (C) and testosterone propionate (TP) administration (C+TP or $\mathrm{H}+\mathrm{TP}$ ) on prostanoid synthesis by (a) 35-day-old or (b) 100-day-old vas deferens tissue in the presence of exogenous arachidonic acid $(10 \mu \mathrm{g} / \mathrm{ml} / 20 \mathrm{ml}$ of tissue). Values are mean \pm s.e.m. for the no. of experiments indicated in parentheses. Control animals were untreated.

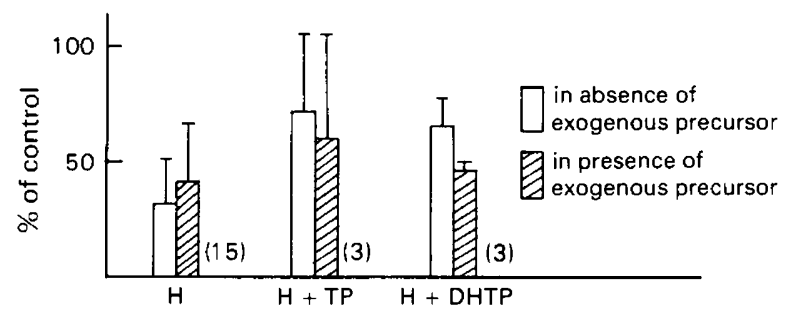

Text-fig. 3. Effect of the administration of testosterone propionate or $5 \alpha$-dihydrotestosterone propionate $(250 \mu \mathrm{g} /$ day for 14 days), on PGE-2 production by vas deferens tissue of 35 -day-old hypophysectomized rats. Values are mean \pm s.e.m. for the no. of experiments indicated in parentheses. Control animals were unoperated and untreated.

genital tract. In this study, we have not measured immunoreactive PGD-2. When the vas deferens was incubated with $\left[{ }^{14} \mathrm{C}\right]$ arachidonic acid, negligible amounts of $\left[{ }^{14} \mathrm{C}\right] P G D-2$ were obtained after rp-HPLC separation of the prostanoids.

The present results show that the in-vitro production of PGE-2 and PGF- $2 \alpha$ is under pituitary and gonadal control: PG levels decrease after hypophysectomy or castration, and are reinstated after treatment with testosterone propionate. The comparison carried out between the evolution of PGE-2 and PGF- $2 \alpha$ shows that PGE-2 is much more sensitive than PGF- $2 \alpha$ to the various 
manipulations applied. Similar results, based on endogenous PGE-2 and PGF- $2 \alpha$ in the rat or mouse vas deferens, have been reported by others (Bartke \& Koerner, 1974; Badr, Barcikowski \& Bartke, 1975; Bartke, 1976), but our results differ from those obtained by Borda, Peredo, Agostini, Gimeno \& Gimeno (1981) who reported that testosterone regulates PGF but not PGE production by the rat vas deferens. The discrepancy between this study and our own results may be due to different experimental conditions: Borda et al. (1981) performed castration in adult animals and testosterone administration was started 20 days post-operatively. It is well known that the timing of castration, before or after puberty, influences the male tract in various ways. In addition, the administration of androgens, starting either on the day of operation or later, has different effects. Finally, the dose of testosterone administered, the experimental conditions of tissue incubation and the analytical methods employed could be responsible, in part at least, for these different observations.

The fact that PGI-2 production in vitro is not controlled in the same way as PGE-2 and PGF- $2 \alpha$ is shown by the absence of significant variations after the different manipulations. This, together with the fact that PGI-2 predominates before puberty and especially in the immature rat, poses the question as to the different cellular origin of PGI-2 in the vas deferens. It is possible that PGI-2 is of vascular origin (Birkle, Wright, Ellis \& Ellis, 1981) and may not respond to the hormone changes which occurred during this study.

The production of prostanoids by the immature animal proves that these substances do not originate from spermatozoa which are not present at this stage. On the basis of results obtained in adult animals with ligated vasa deferentia, Bartke \& Koerner (1974) have already suggested that the spermatozoa are not the source of PGs in the vas deferens. The importance of these prostanoids is underlined by the alterations which their administration provokes in the vas deferens (Chinoy \& Chinoy, 1981).

We thank Mrs A. M. Le Bouder and P. Nicolas for technical assistance and Mrs M. Berson and E. Pagis for secretarial assistance. This work was supported by a grant from DGRST 80.E.0805.

\section{References}

Badr, F.M., Barcikowski, B. \& Bartke, A. (1975) Effect of castration, testosterone treatment and hereditary sterility on prostaglandin concentration in the male reproductive system of mice. Prostaglandins 9, 289297.

Bartke, A. (1976) Prostaglandins and the function of the male reproductive system. In Regulatory Mechanisms of Male Reproductive Physiology, pp. 79-86. Ed. C. H. Spilman et al. Excerpta Medica, Amsterdam.

Bartke, A. \& Koerner, J. (1974) Androgenic regulation of concentration of prostaglandin $F$ in the male reproductive system of rats and mice. Endocrinology 95, 1739-1743.

Birkle, D.L., Wright, K.F., Ellis, C.K. \& Ellis, L.F. (1981) Prostaglandin levels in isolated brain microvessels and in normal and norepinephrine stimulated cat brain homogenates. Prostaglandins 21, 865-877.

Borda, E., Peredo, H., Agostini, M., Gimenó, M.F. \& Gimeno, A.L. (1981) Testosterone regulated prostaglandin production by the rat vas deferens. Prostaglandin Med. 7, 245-251.

Carpenter, M.P. (1974) Prostaglandins of rat testis. Lipids 9, 397-406.

Chinoy, N.Y. \& Chinoy, M.R. (1981) Infertility induced by prostaglandins in albino rats by adrenergic block in the vas deferens. Int. J. Fert. 96, 1-7.

Dray, F. \& Gerozissis, K. (1979) Interrelationships between androgens and prostaglandins in the vas deferens of prepubertal rats. Arch. Androl. 2, 189196.

Dray, F., Charbonnel, B. \& Maclouf, J. (1975) Radioimmunoassay of prostaglandins $F_{\alpha}, E_{1}$ and $E_{2}$ in human plasma. Eur. J. clin. Invest. 5, 311-318.

Dray, F., Gerozissis, K., Kouznetzova, B., Mamas, S., Pradelles, P. \& Trugnan, G. (1980) New approach to the RIA of prostaglandins and related compounds using jodinated tracers. Adv. Prostaglandins Thromboxane Res. 6, 167-180.

Gerozissis, K. \& Dray, F. (1977a) Selective and agedependent changes of prostaglandin E-2 in the epididymis and vas deferens of the rat. J. Reprod. Fert. 50, 113-115.

Gerozissis, K. \& Dray, F. (1977b) Prostaglandins in the isolated testicular capsule of immature and young adult rats. Prostaglandins 13, 777-783.

Johnson, J.M. \& Ellis, L.C. (1977) The histochemical localization of prostaglandin synthetase activity in the reproductive tract of the male rat. J. Reprod. Fert. 51, 17-22.

Sors, H., Pradelles, P., Dray, F., Rigaud, M., Maclouf, J. \& Bernard, P. (1978) Analytical methods for thromboxane $B_{2}$ measurement and validation of radioimmunoassay by gas liquid chromatography-mass spectrometry. Prostaglandins 16, 277-290. 